\title{
〔原著〕
}

\section{パルスフィールドゲル電気泳動法 $(\mathrm{PFGE})$ による Thermophilic Campylobacter 3 菌種の DNA 解析}

\author{
松田基夫*・松本一政 $* *$. 金内長司 $* *$ ・政岡俊夫*** \\ 赤堀文昭***・山田隆紹
}

\begin{abstract}
SUMMARY
In order to determine the suitable conditions for gaining distribution of DNA fragments useful for the chromosomal DNA analysis of the thermophilic Campylobacter, C. coli, C. jejuni and C. laridis, we were interested in the poor $\mathrm{G}+\mathrm{C}$ content of the chromosomal DNAs and the intact DNAs embedded in agarose blocks were digested with 15 restriction enzymes which can recognize sequences containing only $\mathrm{G}$ and $\mathrm{C}$ nucleotides (NotI, SfiI, ApaI, BglI, SacII, SmaI and HpaII), sequences rich with G and C (BamHI, KpnI, PstI, SalI and XhoI) and some other sequences (DraI, EcoRI and HindIII) respectively. The resulted restriction fragments were fractionated by pulsed-field gel electrophoresis.

When the chromosomal DNAs prepared from the 3 Campylobacter strains were digested with two restriction enzymes (NotI and SfiI) available with 8-base recognition, electrophoretic profiles of the digested chromosomal DNAs were shown to be very similar to those of each undigested chromosomal DNAs, respectively.

The DNAs digested with EcoRI migrated at the same level as each undigested chromosomal DNAs by unknown reason(s).

Twelve other restriction enzymes were able to cut the DNAs from the 3 Campylobacter strains with the exception that $K p n I$ did not cut the DNA from the $C$. jejuni strain. Among the enzymes, ApaI, SalI and SmaI cut the DNAs from the 3 Campylobacter strains into a relatively limited number of restriction fragments in the range of approximately $50-1,500 \mathrm{~kb}$ in length.

Thus, three restriction enzymes, ApaI, SalI and SmaI, were found to produce distributions of DNA fragments useful for chromosomal DNA analysis of the 3 Campylobacter strains by pulsed-field gel electrophoresis.

Moreover, the genome size of the 3 bacterial strains were preliminarily estimated to be approximately $2,000 \mathrm{~kb}$ for C. coli JCM $2529^{\mathrm{T}}, 1,900 \mathrm{~kb}$ for C. jejuni JCM 2013 and $1,700 \mathrm{~kb}$ for C. laridis JCM $2530^{\mathrm{T}}$ in length, respectively.
\end{abstract}

Key words: Mb chromosomal DNA analysis, thermophilic Campylobacter strains, pulsed-field gel electrophoresis, ApaI, SalI and SmaI.

DNA analysis of the thermophilic Campylobacter by pulsed-field gel electrophoresis.

* Motoo Matsuda; 麻布大学生物科学総合研究所遺伝子研究部

** Kazumasa Matsumoto, Choji Kaneuchi; 麻布大学獣医学部公衆衛生学第二講座

*** Toshio Masaoka, Fumiaki Akahori ; 麻布大学獣医学部薬理学講座

+ Takatsugu Yamada; 麻布大学獣医学部内科学講座

Correspondence address: Motoo Matsuda, Department of Gene Biology, Azabu University Research Institute of Biosciences, Fuchinobe, Sagamihara 229, Japan.

(受付 1990 年 6 月 20 日, 受理, 1990 年 10 月 8 日) 
はじめに

Campylobacter coli, C. jejuni, C. laridis は好温性 カンピロバクター 3 菌種で, 人畜共通感染症の原因菌, とくに食中毒におけるヒト腸炎起病性菌として近年注目 されている1 3). しかしとれら Campylobacter 3 菌種 (以下 C. 3 菌種) の染色体 DNA の分子生物学的性状 に関する報告は少なく，ゲノムの全長やフィジカルマッ プをはじめとしてその染色体 DNA の性状に関しては 不明のままである。

一方, 近年メガベース単位での DNA 解析がパルス フィールドゲル電気泳動法 (PFGE) の開発4)により可能 となり原核細胞・真核細胞を問わず巨大染色体単位での 解析が行われる様になってきた. PFGE 法はゲルの四方 に電極を設置し向かい合う電極間で互いに 2 方向に電場 を連続的に転換させる時間間隔（パルスタイム）により DNA の分画可能範囲を調整するものである. との手法 を用いるととによって, 従来のアガロースゲル電気泳動 法では分画不可能であった数メガベース単位での巨大染 色体 DNA およびその制限酵素消化断片の分画, 解析 が可能となってきた.

そこでわれわれは C. 3 菌種の染色体 DNA のメガ ベース単位での解析に，より適した条件をスクリーニン グにより確定する事を目的として，その $\mathrm{G}+\mathrm{C}$ 含量がと あに 30〜34\%と低(5)ことに着目して，GC に富む塩基 配列を認識する酵素をはじめ 15 種類の制限酵素を用い てそれぞれアガロースブロックに包埋された無傷の巨大 染色体 DNA の切断実験を行い PFGE を用いる手法で これら C. 3 菌種の DNA 解析を行った。

\section{材料および実験方法}

\section{1. 材料: 菌株 (Table 1)}

使用菌株はブタ由来 C. coli JCM 2529 $\mathrm{T}$, ヒト由来 $C$. jejuni JCM 2013 および力モメ由来 C. laridis JCM $2530^{\mathrm{T}}$ でいずれあ基準株あるいはそれに準ずるあのであ った. Saccharomyces cerevisiae X 2180-1A はその染 色体 DNA を電気泳動の際の DNA サイズマーカーと して用いた。

\section{2. 方 法}

1）アガロースブロック法による DNA インサート の調製

アガロースブロック法は細胞をアガロース中に封入し た状態で DNA を抽出, 制限酵素で消化する方法で, こ の方法では DNA の物理的切断が少なく巨大染色体
Table 1. Strains used in this study.

\begin{tabular}{|c|c|c|}
\hline Organism & Strains & Obtained from: \\
\hline Campylobacter coli & \multicolumn{2}{|c|}{ JCM $2529^{\mathrm{T}, \mathrm{a}} \mathrm{JCM}^{\mathrm{b}}$} \\
\hline Campylobacter jejuni & JCM 2013 & $\mathrm{JCM}$ \\
\hline Campylobacter laridis & $\mathrm{JCM} 2530^{\mathrm{T}}$ & JCM \\
\hline $\begin{array}{l}\text { Saccharomyces } \\
\text { cerevisiae }\end{array}$ & X 2180-1A & S. Murakamic \\
\hline
\end{tabular}

a $T$, the type strain

b JCM, Japan Collection of Microorganisms, Wako, Saitama 351-01, Japan.

c Department of Biophysics, Cancer Research Institute Kanazawa University, Kanazawa 920, Japan

\section{DNA が得られる4).}

まず集菌した細菌細胞を $10 \mathrm{mM}$ Tris- $\mathrm{HCl}$ [pH 7.6] $1 \mathrm{M} \mathrm{NaCl}$ で洗浄し, 遠心後上記緩衝液に再懸濁して, これと等量の $1 \%$ 低融点アガロース (FMC, Incert ${ }^{\mathrm{TM}}$ ) 水溶液を混合し，インサートモールド $[10 \times 5 \times 2 \mathrm{~mm}$ $(100 \mu 1)]$ 中に注入後す速く $4^{\circ} \mathrm{C}$ で固型化した. なお用い た細菌細胞数は約 $5 \times 10^{7} /$ インサートモールドとなるよ う調製した。 ついでとれらアガロースブロックを $6 \mathrm{~mm}$ Tris- $\mathrm{HCl}$ [pH 7.6], $1 \mathrm{M} \mathrm{NaCl}, 100 \mathrm{mM}$ EDTA [pH 7.5], 0.5\% Brij 58 (シグマ社 P 5884), 0.2\% デオキ シコール酸ナトリウム, $0.5 \%$ Lauroy1 Sarcosine を含 む緩衝液 (Lysis 溶液) 中でリゾチーム（終濃度 $1 \mathrm{mg} /$ $\mathrm{ml}$; 和光純薬) と RNase（終濃度 $20 \mu \mathrm{g} / \mathrm{ml}$; シグマ社） で $37^{\circ} \mathrm{C}$ 一晚消化して細菌細胞をスフェロプラスト化し た.さらにプロティナーゼ $K$ (終濃度 $1 \mathrm{mg} / \mathrm{ml}$; 和光純 薬) を含む 0.5 M EDTA [pH 9.0], 1\% Lauroyl Sarcosine (シグマ社 L-5125) 中で $50^{\circ} \mathrm{C}, 2$ 日間消化して 蛋白質を分解除去し，無傷の巨大染色体 DNA を含む アガロースブロックを調製した。

2）制限酵素による DNA の消化

今回の実験に使用した制限酵素（東洋紡および宝酒 造）とその認識配列を Table 2 に示した. 酵素反応は 32〜80 ユニットの制限酵素を含む反応溶液 $(150 \mu \mathrm{l})$ 中 で通常は $1 / 2$ ブロック $(50 \mu 1)$ を用いて 4 時間行った. なお反応液と反応温度はそれぞれ酵素の発売元の指定に 従って行った.

3). PFGE 法による DNA 消化断片の分画

今回われわれはファルマシア LKB 社製 Pulsaphor ${ }^{\mathrm{TM}}$ システムを使用した。 まず水平なトレー上に作られた $1 \%$ \%ガロースゲル $(16 \times 16 \times 0.5 \mathrm{~cm}$; 宝アガロース LO3)のウエル中に $1 / 2$ アガロースブロックを挿入した. 電気泳動は電極が均一な電場の形成されるように工夫さ 
Table 2. Restriction enzymes used in this study.

\begin{tabular}{cl}
\hline Restriction enzyme & Recognition sequence \\
\hline 1) NotI & GC'GGCCGC \\
SfiI & GGCCNNNN'NGGCC \\
2) ApaI & GGGCC'C \\
BamHI & G'GATCC \\
BglI & GCCNNNN'NGGC \\
DraI & TTT'AAA \\
EcoRI & G'AATTC \\
HindIII & A'AGCTT \\
KpnI & GGTAC'C \\
PstI & CTGCA'G \\
SacII & CCGC'GG \\
SalI & G'TCGAC \\
SmaI & CCC'GGG \\
XhoI & C'TCGAG \\
3paII & C'CGG \\
\hline
\end{tabular}

Restriction enzymes are available with 8 base recognition 1), 6 base recognition 2) and 4 base recognition 3 ), respectively.
れたヘキサゴナル電極を用い，いくつかの予備的な実験 の後に,エディト・ステッピングモードで $200 \mathrm{~V}$,パルス タイムは 70 秒で 15 時間の後, 120 秒で 12 時間, TBE 緩衝液 (89 mM Tris, $89 \mathrm{~mm}$ ほう酸, $2 \mathrm{~mm}$ EDTA) 中, $13^{\circ} \mathrm{C}$ で行った.

電気泳動後のゲルは Ethidium Bromide $(1 \mu \mathrm{g} / \mathrm{ml})$ で 染色し, トランスイルミネータ下で観察した.

\section{実 験 結果}

今回の実験でわれわれは C. 3 菌種の染色体 DNA の メガベース単位での解析に，より適した条件をスクリー ニングにより確定することを目的として 15 種類の制限 酵素を用いた DNA 解析を行ったが, これら C. 3 菌種 株の染色体 DNA ではまず NotI，SfiI および EcoRI で消化した場合対照として同時に泳動された未消化 DNA インサートの場合と類似の泳動像を示した. これ らのうち EcoRI を用いた場合の結果を Fig. 1 に示し た.ついで用いた 15 種類の制限酵素のうち, これら 3 種類を除く 12 種類では, KpnI による C. jejuni

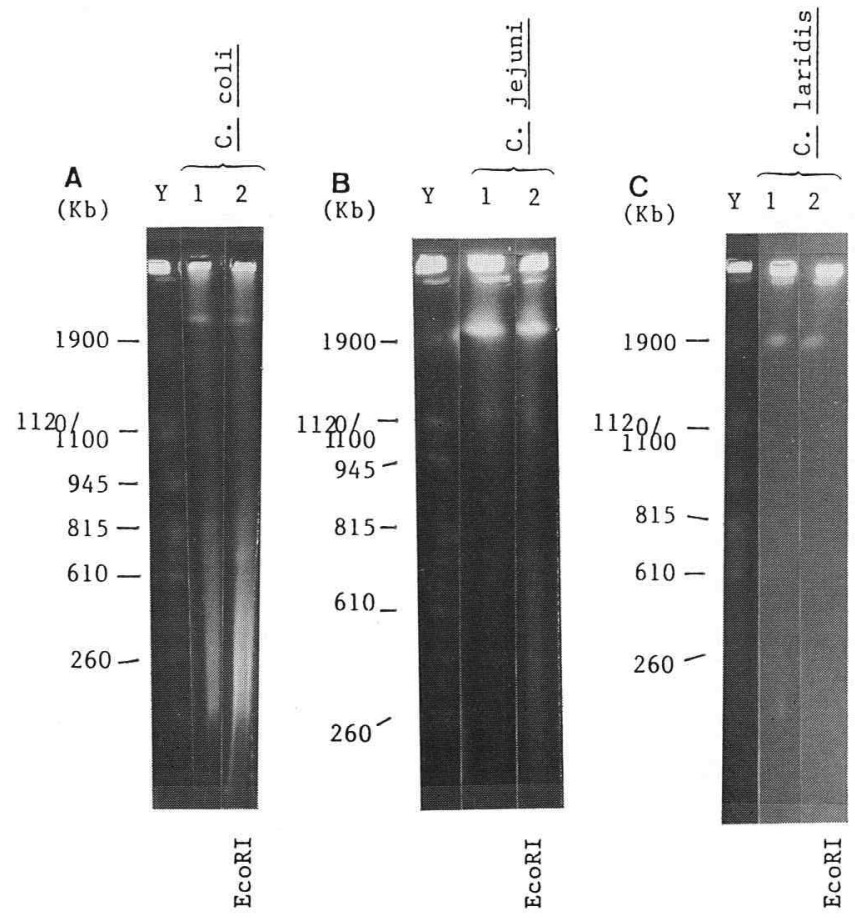

Fig. 1. PFGE separation of EcoRI digested-restriction fragments of chromosomal DNAs. lane Y: chromosomal DNA from Saccharomyces cerevisiae as size marker. (A) lane 1: C. coli DNA undigested. lane 2:C. coli DNA digested with EcoRI. (B) lane 1: C. jejuni DNA undigested. lane 2: C. jejuni DNA digested with EcoRI. (C) lane 1:C. laridis DNA undigested. lane 2:C. laridis DNA digested with EcoRI. 


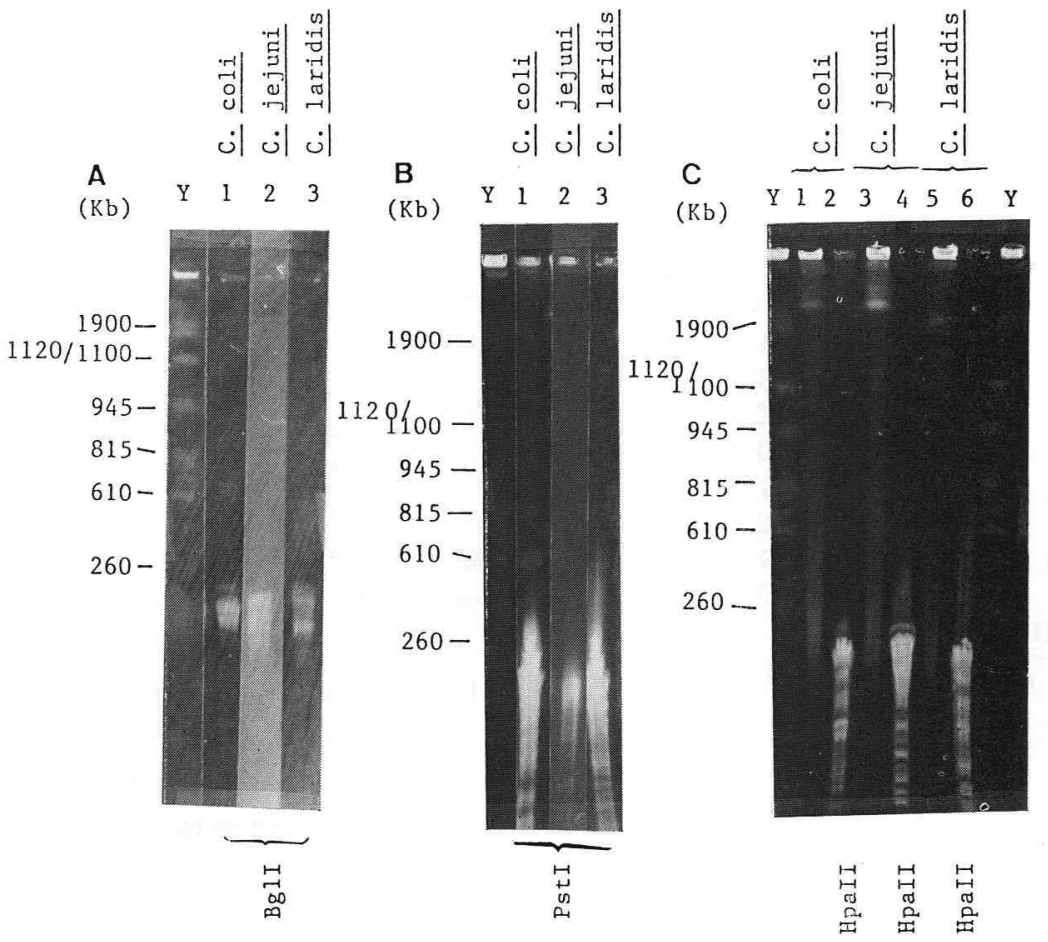

Fig. 2. PFGE separation of restriction fragments of chromosomal DNAs.

lane Y: chromosomal DNA from Saccharomyces cerevisiae as size marker. (A) Digestion with BglI. lane $1:$ C. coli. lane 2:C. jejuni. lane $3:$ C. laridis. (B) Digestion with Pst1. lane 1: C. coli. lane 2: C. jejuni. lane 3: C. laridis. (C) Digestion with HpaII. lane 1: C. co'i DNA undigested. lane 2: C. coli DNA digested with HpaII. lane 3:C. jejuni DNA undigested. lane 4:C. jejuni DNA digested with HpaII. lane 5: C. laridis DNA undigested. lane 6: C. laridis DNA digested with HpaII.

DNA 消化実験の場合を除いてはすべて複数の切断断片 が観察された.これらのうち BamHI, BglI.DraI, HindIII, HpaII お’よび PstI の 6 種類の制限酵素を用 いた場合では, いずれも C. 3 菌種株染色体 DNA は効 率よく切断されて, BglI では $200 \mathrm{~kb}$ 以下の断片が 10 数本, BamHI, PstI では $400 \mathrm{~kb}$ 以下に HpaII では $200 \mathrm{~kb}$ 以下にそれぞれ多数の断片が確認された.

これらのうちで BglI, PstI および HpaII を用いて 得られた実験結果を Fig. 2 亿示した. またDraI，お お よび HindIII では確率的に当然予想されるように泳動 ゲルの先端部分に多くの小さな DNA 断片が確認され た (データ省略). KpnI を用いた場合では C. coli と C. laridis 染色体 DNA でそれぞれ約 $600 \mathrm{~kb}$ 以下の領 域に切断された DNA 断片が検出されたが，C. jejuni DNA では消化切断された DNA 断片は検出されず, 未消化 DNA の領域に相当する部位に止まったままで あった (Fig. 3).

一方, ApaI, SalI および SmaI を用いて消化した
C. 3 菌種の PFGE-EtBr 染色像は約 50 1,500 kb の 間に比較的大きな2〜数個の DNA 切断断片を示し た. それらの結果を Fig. 4 亿示した. Fig. 4 亿示され ているように ApaI では C. coli で 3 個, C. jejuni で 2 個, C. laridis で2 個, SalI ではそれぞれ6，6，3 個またSmaI ではそれぞれ 11，5７，5個の断片が鮮 明に分離検出された。 また Fig. 4 に示されているよう に, 三つの酵素で消化された C. 3 菌種株染色体 DNA はそれぞれ独特の PFGE の泳動パターンを示した.

最後に C. 3 菌種株の ApaI, SalI および SmaI に よる DNA 消化切断断片の電気泳動パターンと, サイ ズマーカーとして用いた S. cerevisiae の染色体の電気 泳動像をとにこれらC. 3 菌種株の染色体 DNA の 全長を推測した. C. coli JCM $2529^{\mathrm{T}}$ で約 $2,000 \mathrm{~kb}$, C. jejuni JCM 2013 で約 1,900 kb および C. laridis $\mathrm{JCM} 2530^{\mathrm{T}}$ では約 $1,700 \mathrm{~kb}$ と推定された. これらは

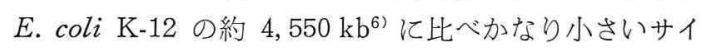
ズであるととが明らかとなった。 


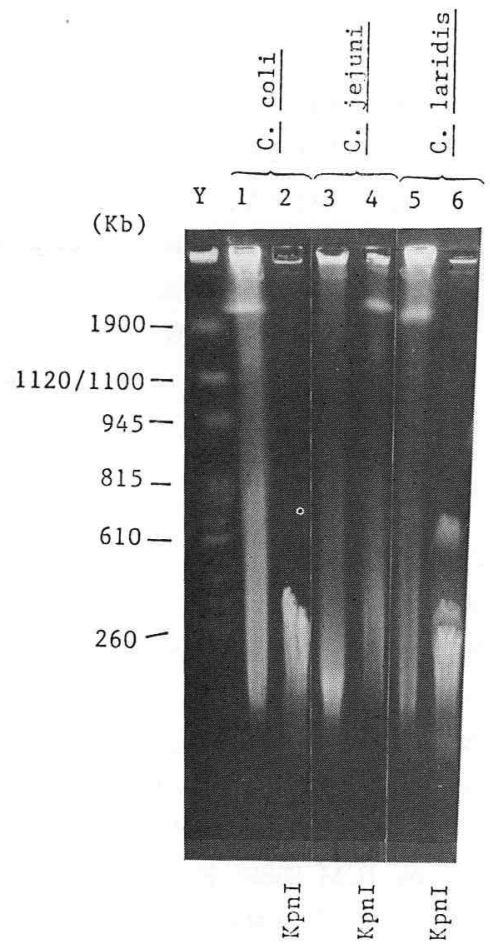

Fig. 3. PFGE separation of KpnI digestedrestriction fragments of chromosomal DNAs. lane Y: chromosomal DNA from Saccharomyces cerevisiae as size marker. lane 1:C. co! $i$ DNA undigested. lane 2. C. coli DNA digested with KpnI. lane 3: C. jejuni DNA undigested. lane 4:C. jejuni DNA digested with $K p n \mathrm{I}$. lane 5:C. laridis DNA undigested. lane $6: C$. laridis DNA digested with KpnI.

\section{考察}

今回の実験において，GC のみから成る配列を認識 する 8 塩基対認識酵素 Not $\mathrm{I}$ および $S f i$ を用いた PFGE による解析では C. 3 菌種株の染色体 DNA は未 消化 DNA 上類似のパターンを示した. このような事 実からは，G+C\% の低いこれら C. 3 菌種株の染色体 DNA 上には両酵素による認識配列が 1 個しか存在しな いか, 存在しないか, あるいは存在しても切断されない 状態になっているか，三つの可能性が考えられる．もち ろん, 実験結果から認識配列が 1 個存在する可能性を考 慮するのはこれらC. 3 菌種株染色体 DNA が閉環状構 造をとっていることを前提とした場合である. 染色体 DNA が閉環状構造の場合, 制限酵素による切断箇所が 1 個だと酵素処理によって染色体 DNA 全体が直鎖状 構造となり末消化のコントロール染色体 DNA と電気

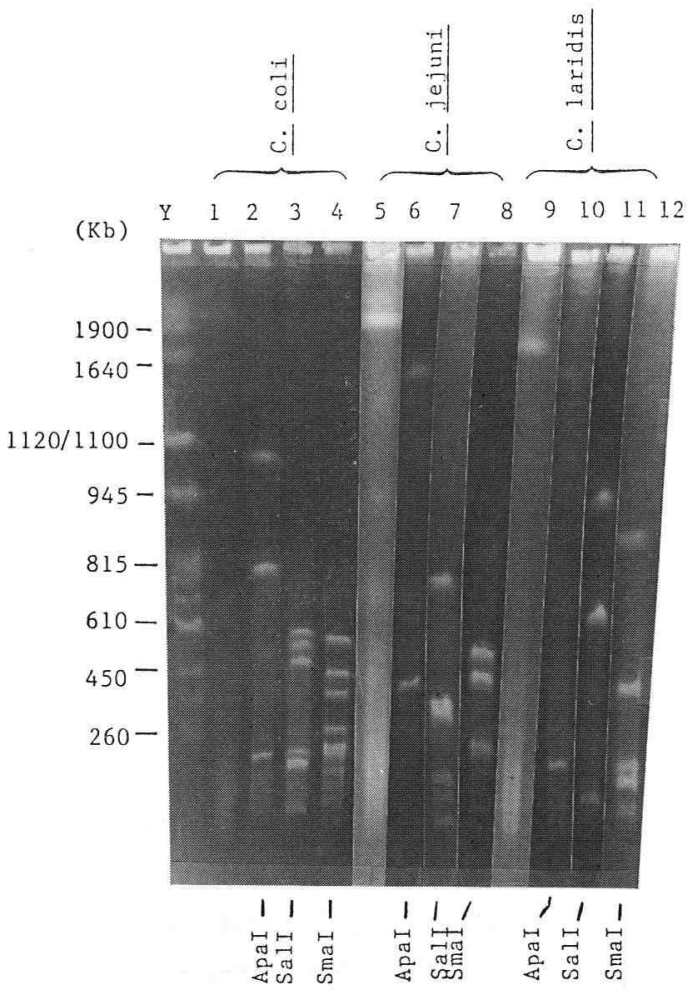

Fig. 4. PFGE separation of restriction fragments of chromosomal DNAs.

lane Y: chromosomal DNA from Saccharomyces cerevisiae lane 1: C. coli DNA undigested. lane 2: C. coli DNA digested with ApaI. lane 3: digested with SalI. lane 4 : digested with SmaI. lane 5:C. jejuni DNA undigested. lane 6:C. jejuni DNA digested with ApaI. lane 7 : digested with SalI. lane 8: digested with SmaI. lane 9: C. laridis DNA undigested. lane 10: C. laridis DNA digested with ApaI. lane 11: digested with SalI. lane 12: digested with SmaI.

泳動上類似の移動度を示すようになりうるかむしれない からである. との点については ApaI 等との二重消化 実験を含めさらに検討が必要で現在これらを実施してい るとてろである.われわれが用いた Not I，SfiI につい ては E. coli K-12 ML-1410 株の染色体 DNA を用い た予倫的実験で, Smith らが報告している泳動パター ン6) とそれぞれ高い類似性を示したので酵素活性に関す る問題点は当然除去されうる. このように Not I，Sfi に関してはわれわれが当初実験目的とした C. 3 菌種の 染色体 DNA の「メガベース単位での解析に適した制 限酵素」ではないことが明らかとなったＥcoRI を用 いた実験の場合確率論的にはさきに述べた三つの可能性 
（112） 生物物理化学

の 1 番 2 番目を想定するのは困難であり, 3 番目の「存 在しても切断されない状態」すなわち C. 3 菌種株 DNA 上の $E c o$ RI 認識配列中のメチル化等の可能性を考慮に 入れるべきであろう. KpnI に関しては，他のいずれの 酵素を用いた場合とも異なり C. coli と C. laridis は 消化切断されるが C. jejuni 株は未消化 DNA の場合 と類似の泳動像を示すという大変特徽的な結果が得られ た.この結果は大変興味ある事実であり今後詳細な解析 が必要である。

今回用いた酵素のなかで結果は示さなかったが，Sac II および XhoI の場合も 50〜 1, $500 \mathrm{~kb}$ の範囲で C. 3 菌種株 DNA の切断断片が分離検出されたが断片の数 が多くまた分離の度合が鮮明ではなく「メガベース単位 での解析に，より適した条件」を満たすすのとはいえな かった.

今回の実験で C. 3 菌種株の「メガベース単位での解 析に，より適した条件」として 15 種の制限酵素を用い たスクリーニングにより ApaI，SalI 扔よび SmaI の 三つの酵素が合致しているととが明らかとなった。

さて今回われわれが行った PFGE の泳動実験条件で は, 約 $50 \sim 2,000 \mathrm{~kb}$ の DNA の分離分画が可能であ り, C. 3 菌種株染色体 DNA の全長を ApaI, SalI および SmaI を用いた実験結果より推定するには大変 好都合なあのであった. あちろん C. 3 菌種株の染色体 DNA の全長の決定には現在ほとんどその分子遺伝学的 知見のないファージの有無等についても考慮する必要が あるう。

一方, PFGE を用いた細菌巨大染色体 DNA の解析 に関する報告は少ないが, 最近, 大腸菌 $\mathrm{K}-12^{6)}$, ラクト コッカス属菌"), クラミジア菌8)，ミュータンスレンサ球 菌9), コウロバクター属菌 ${ }^{10)}$ 等で報告があいつぎ，乙れ まで未決定のままであった各種染色体 DNA の全長の 決定やフィジカルマップの作製等を具体的解析内容とし て独自の研究領域を形成しつつあり今後の急速な新展開 が強く示唆される.

\section{ま と め}

われわれは thermophilic Campylobacter 3 菌種 (C. coli, C. jejuni, C. laridis) の染色体 DNA のメガベー ス単位での解析に，より適した条件をスクリーニングに より確定することを目的として，てれら C. 3 菌種染色
体 DNA の GC 含量が低いととに着目し，その認識配 列中に $\mathrm{G}+\mathrm{C}$ をすべてかあるいは多くを含む酵素をは じめ 15 種類の制限酵素を用いて, 染色体 DNA の消化 をアガロースブロック法で行った後, PFGE によってそ の染色体断片の解析を行った。

まずNotI，SfiI を用いた実験ではC. 3 菌種株染 色体 DNA は未消化 DNA と類似の泳動像を示し, NotI，SfiI は上記実験目的に合致しないととが明ら かとなった. BglI, XhoI をはじめ他の 10 種類の制 限酵素の場合む PFGE による実験結果より「染色体 DNA のメガベース単位での解析に，より適した条件」 を備えていなかった。

一方，ApaI，SalI および SmaI の三つの制限酵素 では C. 3 菌種染色体 DNA をそれぞれ 50 1,500 $\mathrm{kb}$ の範囲で 2 11 個の断片に切断し, C. 3 菌種はそれ ぞれ異なる独特の泳動像を示した.また ApaI, SalI および SmaI を用いた実験結果より，われわれは今回 はじめて C. 3 菌種染色体 DNA の全長を C. coli JCM $2529^{\mathrm{T}}$ 約 $2,000 \mathrm{~kb}$, C. jejuni JCM 2013 約 1,900 kb お よび C. laridis JCM $2530^{\mathrm{T}}$ 約 $1,700 \mathrm{~kb}$ と予測した.

以上の結果より C. 3 菌種染色体 DNA の全長の決定 やフィジカルマップの作成などを内容とした DNA 解 析にはApaI, SalI 执よび SmaI と PFGE を用いる 手法が適していることが明らかとなった。

S. cerevisiae X 2180-1A 株を分与いただいた 金沢大 学がん研究所村上清史先生に深謝します.

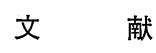

1) Skirrow, M. B. : J. Hyg. Camb., 89 : 175, 1982.

2) Fricker, C. R. et al.: J. Hyg., 91 : 445, 1983.

3) Blaser, M. J. et al. : Campylobacter Infection in Man and Animals, Butzler, J.P. (ed.), [CRC Press, BocaRaton Florida, 1984, p. 143.

4) Schwartz, D. C. and Cantor, C. R. : Cell, $37: 67$, 1984.

5) Benjamin, J. et al.: Curr. Microbiol., $8: 231$, 1983.

6) Smith, C. L. et al. : Science, 236 : 1448, 1987.

7) Bourgeois, P. L. et al. : FEMS Microbiol. Lett., $59: 65,1989$.

8) Frutos, R. et al.: J. Bacteriol., 171 : 4511, 1989.

9）岡崎暢夫, 他: 日本細菌学雑誌, $45: 272,1990$.

10) Ely, B. et al. : J. Bacteriol., 172: 1262, 1990. 